\title{
BUCKLING ANALYSIS OF LINE CONTINUUM WITH NEW MATRICES OF STIFFNESS AND GEOMETRY
}

\author{
C.N Okoli ${ }^{1}$, J.C. Ezeh $^{2}$, O.M. Ibearugbulem ${ }^{3}$ \\ ${ }^{1,2,3}$ Civil Engineering Department, Federal University of Technology, Owerri, Nigeria
}

\begin{abstract}
This research work present buckling analysis of line continuum with new matrices of elastic stiffness and geometric stiffness. The stiffness matrices were developed using energy variational principle. Two deformable nodes were considered at the centre and at the two ends of the continuum which brings the number of deformable node to six. The six term Taylor McLaurin's shape function was substituted into strain energy equation and the result functional was minimized, resulting in a 6 x 6 stiffness matrix used herein. The six term shape function is also substituted into the geometric work equation and minimized to obtain $6 \times 6$ geometric stiffness matrix for buckling analysis. The two matrices were employed, as well as traditional $4 \times 4$ matrices in classical buckling analysis of four line continua. The results from the new $6 \times 6$ matrices of stiffness and geometry were very close to exact results, with average percentage difference of 2.33\% from exact result. Whereas those from the traditional $4 \times 4$ matrices and $5 \times 5$ matrices differed from exact results, with average percentage difference of 23.73\% and 2.55\% respectively. Thus the newly developed $6 \times 6$ matrices of stiffness and geometry are suitable for classical buckling analysis of line continuum.
\end{abstract}

Keywords: $6 x 6$ stiffness system; buckling; geometry; line continuum; variational principle; deformable node; shape function; classical; numerical; analysis; beam

\section{INTRODUCTION}

The design of multi-storey building frames requires that a structural engineer is familiar with structural instability that can occur in such a building. Hence, thorough analysis and calculations is required. However, the classical method of analysis using the traditional $4 \times 4$ stiffness matrix system tends to find solution that are close to exact solution. Unfortunately, as observed by Ibearugbulem et al (2013), the traditional $4 \times 4$ stiffness matrix and its load vector cannot classically analyze flexural line continua except using them numerically. This difficult in using the traditional classical approach is evident in the work of Iyengar (1988), Chopra (1995) and Yoo and Lee (2011). The traditional $4 \times 4$ numerical method of analysis (more than one element in one continuum) becomes a good alternative to the tradition $4 \mathrm{x} 4$ classical method. The problem with numerical method is that, it is tedious (Melosh, 1963; Long, 1973, 1992, 2009. Cook et al, 1989; Huebner et al, 1995; Bath, 1996; Zienkiewicz and Taylor, 2000; Ibearugbulem et al, 2013) and frequently give results that differ greatly with exact classical results. Hence there is need for classical matrix approach that would be less cumbersome and at the same time give results that are close to exact results. Ibearugbulem et al (2013) developed 5 x 5 stiffness matrices capable of classically analyzing stability and dynamic line continuum, but some of their solutions are not yet exact solution. This work present buckling analysis of line continuum with new matrices of stiffness and geometry. The governing differential equation of line continuum is first integrated to obtain a general solution of the continuum that has specific number of terms. The general solution obtained is used in energy variational principle to get a new and more reliable $6 \times 6$ stiffness matrices for classical buckling analysis of line continuum.

\section{DIRECT INTEGRATION OF GOVERNING EQUATION}

The line continuum governing equation is:

$$
\frac{d^{4} w}{d x^{4}}-N \frac{d^{2} w}{d x^{2}}=0
$$

The solution of the equation (1) is assumed thus:

$$
\operatorname{EIW}(x)=\frac{C_{5} x^{5}}{120}+\frac{C_{4} x^{4}}{24}+\frac{C_{3} x^{3}}{6}+\frac{C_{2} x^{2}}{2}+C_{1} x+C_{0}
$$

Equation (2) can be written as:

$$
\begin{aligned}
& w(x)=a_{0}+a_{1} x+a_{2} x^{2}+a_{3} x^{3}+a_{4} x^{4}+a_{5} x^{5} \\
& \text { where } a_{0}=\frac{c_{0}}{E I} ; a_{1}=\frac{c_{1}}{E I} ; a_{2}=\frac{c_{2}}{2 E I} ; a_{3}=\frac{c_{3}}{6 E I} ; a_{4}=\frac{c_{4}}{24 E I} ; a_{5}=\frac{C_{5}}{120 E I} \text { ) }
\end{aligned}
$$




\section{ENERGY VARIATIONAL PRINCIPLE}

From Naschie (1990), strain energy is given as:

$$
U_{s}=\frac{E I}{2} \int_{0}^{L}\left(W^{I I}\right)^{2} d x
$$

Work performed by in-plane load (stability)

$$
U_{g}=\frac{-P}{2} \int_{0}^{L}\left(W^{I}\right)^{2} d x
$$

\section{NEW STIFFNESS MATRICES FOR}

\section{CLASSICAL BUCKLING}

The new stiffness matrices for classical buckling of line continuum are presented by considering deformable nodes at the centre, and ends of line continuum (each node with two degrees of freedom to bring the number of deformable nodes to six). The forces corresponding to the deformable nodes as illustrated in figure 1 are:

Nodes $=\left[W_{1} \theta_{1} W_{2} \theta_{2} W_{3} \theta_{3}\right]$

$[F E A]=\left[Q F_{1} M F_{1} Q F_{2} M F_{2} Q F_{3} M F_{3}\right]$

Where [FEA] is Fixed End Action or Forces [Nodes] means deformable nodes

$$
K . E=\frac{E I}{L^{3}} *
$$

$\left[\begin{array}{cccccc}145.4857143 & 32.51428571 L & -102.4 & 54.85714286 L & -43.08571429 & 6.914285714 L \\ 32.51428571 L & 9.485714286 L^{2} & -25.6 L & 9.142857143 L^{2} & -6.914285714 L & 1.085714286 L^{2} \\ -102.4 & -25.6 L & 204.8 & -4.55 E-13 L & -102.4 & 25.6 L \\ 54.85714286 L & 9.142857143 L^{2} & 0 L & 36.57142857 L^{2} & 54.85714286 L & 9.142857143 L^{2} \\ -43.08571429 & -6.914285714 L & -102.4 & 54.85714286 L & 145.4857143 & -32.51428571 L \\ 6.914285714 L & 1.085714286 L^{2} & 25.6 L & 9.142857143 L^{2} & -32.51428571 L & 9.485714286 L^{2}\end{array}\right]$

$$
[\text { K.E } E]_{G}=\frac{P}{L} *
$$

$$
\left[\begin{array}{cccccc}
2.647619048 & 0.061904762 \mathrm{~L} & -2.438095238 & 0.380952381 \mathrm{~L} & -0.20952381 & -0.014285714 \mathrm{~L} \\
0.061904762 \mathrm{~L} & 0.044444444 \mathrm{~L}^{2} & -0.076190476 \mathrm{~L} & -0.012698413 \mathrm{~L}^{2} & 0.014285714 \mathrm{~L} & -0.007936508 \mathrm{~L}^{2} \\
-2.438095238 & -0.076190476 \mathrm{~L} & 4.876190476 & 8.88178 \mathrm{E}-14 \mathrm{~L} & -2.438095238 & 0.076190476 \mathrm{~L} \\
0.380952381 \mathrm{~L} & -0.012698413 \mathrm{~L}^{2} & 2.27374 \mathrm{E}-13 \mathrm{~L} & 0.406349206 \mathrm{~L}^{2} & -0.380952381 \mathrm{~L} & -0.012698413 \mathrm{~L}^{2} \\
-0.20952381 & 0.014285714 \mathrm{~L} & -2.438095238 & -0.380952381 \mathrm{~L} & 2.647619048 & -0.061904762 \mathrm{~L} \\
-0.014285714 \mathrm{~L} & -0.007936508 \mathrm{~L}^{2} & 0.076190476 \mathrm{~L} & -0.012698413 \mathrm{~L}^{2} & -0.061904762 \mathrm{~L} & 0.044444444 \mathrm{~L}^{2}
\end{array}\right]
$$

$\mathrm{K}$ and $\mathrm{K}_{\mathrm{g}}$ are the required new $6 \times 6$ matrices of stiffness and geometry for classical buckling analysis of line continuum as shown in equation (11) and (12) respectively.

Where $\Delta$ is the nodal deformation vector expressed in equation (10)

$$
[\Delta]^{T}=\left[W_{1} \theta_{1} W_{2} \theta_{2} W_{3} \theta_{3}\right]
$$




\section{CLASSICAL APPLICATION TO STABILITY}

\section{ANALYSIS}

Four line continua with four different boundary conditions were analyzed for critical buckling loads using the present $6 \mathrm{x}$ 6 matrices of stiffness and geometry and the traditional $4 \times 4$ stiffness systems. The four different boundary conditions are:

a. $\quad \mathrm{P}-\mathrm{R}$ Line Continuum: One end is pinned and the other end is on roller.

b. $\quad \mathrm{C}-\mathrm{C}$ Line Continuum: Both ends are clamped

c. $\quad \mathrm{C}-\mathrm{R}$ Line Continuum: One end is clamped and the other end is on roller

d. $\quad$ C $-\mathrm{F}$ Line Continuum: One end is clamped and the other end is free

\section{RESULTS AND DISCUSSIONS}

The critical buckling load, Pcr were determined from classical analysis of: $4 \times 4,5 \times 5$, and $6 \times 6$ matrices (stiffness and geometry).The comparison of these data with the exact critical buckling loads for the four different boundary conditions were presented in table 1 . It is observed from table 1 , that the comparison of the data from the conventional $4 \times 4$ system and the exact solution shows that the traditional $4 \times 4$ differ very much from the exact solution, excepts for cantilever $(\mathrm{C}-\mathrm{F})$ beam. The percentage differences of $48.59 \%$ and $21.7831 \%$ for propped cantilever $(\mathrm{C}-\mathrm{R})$ beam and simply supported $(\mathrm{P}$ - R) beam; and the average percentage difference of $23.72 \%$ for the $4 \times 4$ stiffness system is very high to be ignored. It was not possible for classical analysis of clamped $(\mathrm{C}-\mathrm{C})$ beam with the traditional $4 \times 4$ stiffness system. Also, the comparison of the data from the present study and classical exact solution shows that the result from this present study are very close to exact result. The highest percentage difference of $6.46 \%$ for clamped $(\mathrm{C}-\mathrm{C})$ beam was recorded. The average percentage difference of $2.33 \%$ of the $6 \times 6$ stiffness matrix system from exact result is minimal and quite acceptable The data from 5 x 5 matrix system (Ibearugbulem et al, 2013) showed better closeness to exact solution than the $4 \times 4$ system. However, the data from the present $6 \times 6$ system are better than those of 5 x 5 system. These outcomes implied that the result from the present study is more close to exact solution than that of Ibearugbulem et al. Hence, the newly developed stiffness matrices are suitable for classical buckling analysis of line continuum.

Table 1: Critical Buckling Load of the Continuum, Pcr $\left(\frac{E I}{L^{2}}\right)$ from Classical Analysis

\begin{tabular}{|c|c|c|c|c|c|c|c|}
\hline $\begin{array}{l}\text { Continua } \\
\text { Boundary } \\
\text { Conditions }\end{array}$ & $\begin{array}{l}\text { Exact } \\
\text { Result } \\
\text { (Pcr) }\end{array}$ & $\begin{array}{l}\text { Result } \\
\text { From 4x4 } \\
\text { Stiffness } \\
\text { System } \\
\text { (Pcr) }\end{array}$ & $\begin{array}{l}\text { Percentage } \\
\text { Difference with } \\
\text { Exact Result }\end{array}$ & $\begin{array}{l}\text { Result from } \\
5 \times 5 \text { Stiffness } \\
\text { System (Pcr) }\end{array}$ & $\begin{array}{l}\text { Percentage } \\
\text { Difference } \\
\text { with Exact } \\
\text { Result }\end{array}$ & $\begin{array}{l}\text { Result from } \\
\text { 6x6 Stiffness } \\
\text { System (Pcr) }\end{array}$ & $\begin{array}{l}\text { Percentage } \\
\text { Difference } \\
\text { with Exact } \\
\text { Result }\end{array}$ \\
\hline $\mathrm{P}-\mathrm{R}$ Beam & 9.87 & 12.02 & 21.78318136 & 9.88 & 0.10 & 9.875 & 0.050658561 \\
\hline $\begin{array}{ll}\mathrm{C}-\mathrm{C} \\
\text { Beam }\end{array}$ & 39.45 & Impossible & -- & 42 & 6.46 & 42 & 6.463878327 \\
\hline $\begin{array}{ll}\mathrm{C}- & \mathrm{R} \\
\text { Beam } & \end{array}$ & 20.19 & 30 & 48.5884101 & 20.92 & 3.62 & 20.286 & 0.475482912 \\
\hline $\mathrm{C}-\mathrm{F}$ Beam & 2.47 & 2.49 & 0.809716599 & 2.47 & 0.00 & 2.47 & 0.00 \\
\hline $\begin{array}{l}\text { Average \% } \\
\text { Difference }\end{array}$ & & & 23.72710269 & & 2.55 & & 2.330066 \\
\hline \multicolumn{8}{|c|}{$\begin{array}{l}\text { Legend: } \\
\text { P-R represents Simply supported beam } \\
\text { C-C represents Clamped beam } \\
\text { C-R represents propped cantilever beam } \\
\text { C-F represents cantilever beam }\end{array}$} \\
\hline
\end{tabular}




\section{REFERENCES}

[1] Bathe, K.J. (1996). Finite Element Procedures: New Jersey: Prentice - Hall Inc.

[2] Cook, R.D., D.S. Malkus, M.E. Plesha (1989). Concepts and Applications of Finite Element Analysis, $3^{\text {rd }}$ Edn. New York: John Wiley \& Sons Inc.

[3] Chopra, A.K. (1995). Dynamic of Structures: Theory and Applications to Earthquake. New Jersey: Prentice - Hall Inc.

[4] Huebner, K.H., E.A. Thornton, T.G. Byrom (1995). The Finite Element Method for Engineers. New York: John Wiley \& Sons Inc.

[5] Ibearugbulem, O.M., Ettu, L.O. and Ezeh, J.C. (2013). A New Stiffness Matrix for Analysis of Flexural Line Continuum. The International Journal of Engineering and Science, 2(2).

[6] Ibearugbulem, O.M., Ettu, L.O., Ezeh, J.C. and Anya, U.C. (2013). A New Stiffness Matrices for Stability and Dynamic Analysis of Line Continuum. The International Journal of Engineering Research and Development, Vol. 6.

[7] Iyengar, N.G.R. (1988). Structural Stability of Columns and Plates. New York: John Wiley \& Sons.

[8] Long, Y.Q., S.Cen, and Z.F. Long (2009). Advanced Finite Element Method in Structural Engineering Beijing: Tsinghua University Press.

[9] Long, Y.Q. (1992). Introduction to New Finite Element Method. Beijing: Tsinghua University Press.

[10] Long, Y.Q. (1991). Introduction to Finite Element Method. $1^{\text {st }}$ Edn Beijing: Higher Education Press.

[11] Melosh, R.J. (1963). Basis for Derivation for the Direct Stiffness method. AIAA Journal, 1(7): 1631 1637.

[12] Naschie, M.S.E. (1990). Stress, Stability and Chaos in Structural Engineering: An Energy Approach. London McGraw - Hill Book Company.

[13] Yoo, C.H., and Lee C.S. (2011). Stability of Structures: Principles and Applications, Oxford.

[14] Zienkiewiez, O.C., and Taylor, R.L. (2000). The Finite Element Method, $5^{\text {th }}$ Edn, Oxford Butterworth - Heinemamn. 